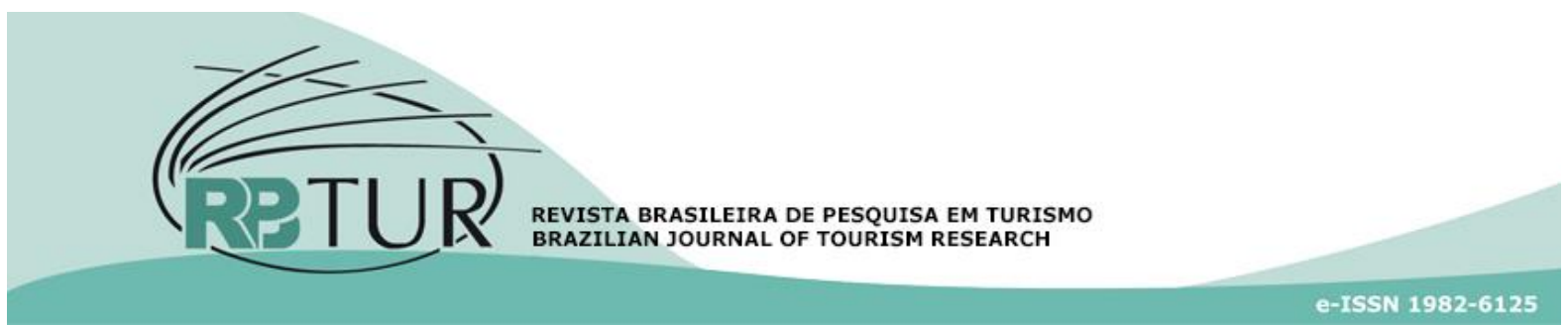

Artigo

DOI: http://dx.doi.org/10.7784/rbtur.v11i3.1314

\title{
Turismo de base comunitária na favela Santa Marta (RJ): oportunidades sociais, econômicas e culturais
}

\author{
Community-based Tourism in Santa Marta Favela/RJ: \\ social, economic and cultural opportunities
}

\section{Turismo de Base Comunitaria en la Favela Santa Marta/RJ: Oportunidades sociales, económicas y culturales}

\author{
Apoena Dias Mano ${ }^{1}$ \\ Verônica Feder Mayer ${ }^{2}$ \\ Aguinaldo Cesar Fratucci ${ }^{3}$
}

Resumo: Propósito justificado do tema: Debates a respeito das motivações e impactos dos processos de turistificação de favelas vêm sendo realizados nos últimos anos, em diversos campos de estudos e em diversos países. Objetivo: Este artigo apresenta os resultados de uma pesquisa realizada na favela Santa Marta, cidade do Rio de Janeiro, com a intenção de se investigar os efeitos do turismo de base comunitária nas atividades turísticas que ocorrem naquele local. Metodologia/Design: Para isso, foram realizados dois estudos: o primeiro, quantitativo, investigou as percepções de turistas e de moradores sobre aspectos positivos e negativos do turismo; o segundo, qualitativo, dedicou-se a compreender a cadeia de turismo de base comunitária local. Resultados e originalidade do documento: Os resultados indicam que alternativas de turismo baseadas no empoderamento e no protagonismo dos moradores podem tornar a prática turística em favelas socialmente mais comprometida. A contribuição central da pesquisa é a reflexão sobre a experiência do Turismo de Base Comunitária em ambientes urbanos como as favelas, indicando que a participação ativa dos moradores pode modificar o perfil do turismo, potencializando as trocas culturais em detrimento da simples observação da pobreza. 0 amadurecimento desse tipo de rede de turismo comunitário está relacionado à desconstrução de estereótipos relacionados às favelas e à obtenção de impactos socioeconômicos e culturais mais positivos e significativos em comparação às formas mais tradicionais de turismo.

Palavras-chave: Turismo em favelas. Turismo de base comunitária. Favela Santa Marta. Rio de Janeiro, Brasil.

\footnotetext{
${ }^{1}$ Universidade Federal Fluminense (UFF). Niterói, RJ, Brasil. Formulação de ideias; elaboração do referencial teórico; coleta e interpretação de dados e preparação do artigo científico.

2 Universidade Federal Fluminense (UFF). Niterói, RJ, Brasil. Desenvolvimento metodológico, processamento e análise de dados; redação e revisão crítica do trabalho.

3 Universidade Federal Fluminense (UFF). Niterói, RJ, Brasil. Orientação metodológica do levantamento qualitativo; redação e revisão crítica do trabalho.
}

Artigo recebido em: 09/05/2017. Artigo aprovado em: 06/07/2017. 


\begin{abstract}
The justified purpose of the theme: Debates about reasons and impacts of slums touristification processes have been carried out over the last years throughout several fields of study in various countries. Objective: This article presents the results of a research conducted in Santa Marta's favela, in the city of Rio de Janeiro, aiming at investigating the effects of community-based tourism on tourism activities that occur in that place. Methodology/Design: To this end, two studies have been undertaken: the first one, quantitative, has investigated tourists' and residents' perceptions of both positive and negative aspects of tourism; the second one, qualitative, was designed to understand local community-based tourism chain. Results and Originality of the Document: The results show that tourism alternatives based on residents' empowering and leading role may turn tourism practices in slums into something more socially committed. The vital contribution of the research is the reflection on the experience of Community-Based Tourism in urban environments such as slums, pointing that active participation of residents can change tourism profile, strengthening cultural exchanges. The ripening of this kind of community tourism network has to do with the deconstruction of stereotypes related to favelas and to the attainment of more positive and significant socioeconomic and cultural impacts in comparison to more traditional forms of tourism.
\end{abstract}

Keywords: Tourism in slums. Community-based tourism. Santa Marta's Favela. Rio de Janeiro, Brazil.

Resumen: Propósito justificado del tema: Debates acerca de las motivaciones y los impactos de los procesos de turistificación de las favelas se han llevado a cabo en los últimos años en diversos campos de estudio y en varios países. Objetivo: Este artículo presenta los resultados de una investigación realizada en la favela Santa Marta, ciudad de Río de Janeiro, con la intención de investigar los efectos del turismo de base comunitaria en las actividades turísticas que se desarrollan en este local. Metodología/Design: Se realizaron dos estudios: el primero, cuantitativo, investigó las percepciones de turistas y residentes sobre aspectos positivos y negativos del turismo; El segundo, cualitativo, se dedicó a comprender la red de turismo local basada en la comunidad. Resultados y originalidad del documento: Los resultados permiten afirmar que las alternativas turísticas basadas en el empoderamiento y el protagonismo de los residentes pueden hacer que la práctica turística en favelas sea más comprometida socialmente. La maduración de esta red de turismo comunitario está relacionada con la deconstrucción de estereotipos relacionados con favelas y la obtención de importantes impactos socioeconómicos y culturales en comparación con las formas tradicionales de turismo.

Palavras clave: Turismo en favelas. Tturismo de base comunitária. Favela Santa Marta. Rio de Janeiro. Brasil.

\section{INTRODUÇÃO}

O interesse e a busca por experiências turísticas diferenciadas, consequência principalmente de novos padrões de consumo no século XXI, levaram à crescente popularização de atividades turísticas em regiões urbanas caracterizadas por contrastes socioeconômicos (Cejas, 2006; Ma, 2010). Conhecido mundialmente como slum tourism (Cejas, 2006; Spampinato, 2009; Klepsch, 2010), no Brasil este polêmico fenômeno tem merecido grande destaque internacional devido ao turismo praticado nas favelas da cidade do Rio de Janeiro (Machado, 2007; Freire-Me- deiros, 2009; Spampinato, 2009; Rodrigues, 2014; Menezes, 2014).

Recentemente, a demanda por roteiros turísticos (Cisne \& Gastal, 2011) nas favelas cariocas tornou-se mais evidente devido à visibilidade internacional do Brasil em razão da realização de eventos como a Copa do Mundo de Futebol, em 2014, e os Jogos Olímpicos e Paralímpicos, em 2016 (Freire-Medeiros, Coelho \& Monteiro, 2012; Rodrigues, 2014). Paralelamente, outro fator fundamental para a ampliação da discussão a respeito da evolução da movimentação turística naqueles locais foi o investimento de políticas públicas no controverso projeto das Unida- 
des de Polícia Pacificadora (UPPs) nas favelas da cidade do Rio de Janeiro (Carvalho \& Silva, 2012; Menezes, 2014).

Sincronicamente ao crescimento dos processos de turistificação (Knafoo, 1996; Fratucci, 2008) das favelas observa-se o aumento de debates e críticas quanto às motivações e interesses dos atores sociais envolvidos pelas atividades turísticas geradas por aqueles processos. Seria o turismo em favelas um processo de mercantilização e espetacularização da pobreza? Seria ele ocasionado pela vontade dos visitantes em ajudar os moradores daquelas áreas? Ou, ainda, seria uma forma de oportunismo por parte dos moradores? Essa temática vem sendo gradualmente analisada por autores de diversas áreas (Cejas, 2006; Freire-Medeiros, 2009; Ma, 2010; Silva et al., 2015).

Diversos trabalhos relacionados a esse tema apontam que, de maneira geral, o planejamento das atividades de turismo em favelas pouco considera a produção de impactos no local (Machado, 2007; Spampinato, 2009; Catão, 2014). Afirma-se que o crescimento do turismo em favelas pode gerar efeitos positivos e negativos, como a geração de empregos, a distribuição de renda, a valorização social, a produtificação cultural e o desencadeamento de processos de gentrificação (Gaffney, 2013).

Com base no pressuposto de que o protagonismo do processo decisório de atividades e serviços turísticos deve pertencer aos moradores locais, o Turismo de Base Comunitária (TBC) se coloca como alternativa para o desenvolvimento das favelas (Spampinato, 2009; Klepsch, 2010).

Gomez et al. (2015) se referem ao TBC como uma nova forma de fazer turismo que se opõe ao turismo de massa e que emerge como iniciativa com potencial de transformação social e de desenvolvimento sustentável local. O desenvolvimento dessas iniciativas se contrapõe aos procedimentos do turismo tradicional, consolidado pelas leis do mercado.

Nesse contexto, pesquisas que relacionem os assuntos Turismo em Favela e Turismo de Base Comunitária se provam relevantes para a obtenção de subsídios capazes de fomentar a expansão de atividades turísticas que tenham como objetivo comum o desenvolvimento sustentável local.

Tendo em vista que, segundo aponta Klepsch (2010), as atividades turísticas com pouco planejamento e envolvimento da comunidade local no processo decisório ocasio nam inúmeros impactos negativos, considerou-se oportuno analisar e registrar a maneira como vem ocorrendo o TBC em uma das primeiras favelas turistificadas da cidade do Rio de Janeiro. Para isso, foram realizadas pesquisas na favela Santa Marta, localizada no bairro de Botafogo, Zona Sul do Rio de Janeiro, cujos resultados ora são apresentados. O objetivo central deste estudo é analisar e discutir as práticas e os efeitos de uma iniciativa de TBC naquela favela.

Como premissas iniciais foram considerados e revistos diversos pontos de discussões sobre o tema, como a fala recorrente de que "turismo em favela é um zoológico de pobreza" (Rodrigues, 2014); impactos econômicos negativos e positivos; valorização cultural e social; resultados da participação comunitária no desenvolvimento do turismo, entre outros. Considera-se que os resultados 
desta pesquisa se tornam importante base de dados para alimentar os frequentes e oportunos debates a respeito do tema.

$\mathrm{O}$ artigo estrutura-se a partir de dois estudos realizados na área selecionada. 0 primeiro tem a forma de pesquisa quantitativa que compara a percepção de moradores e turistas em relação às motivações que levam ao interesse turístico pela favela Santa Marta e suas percepções sobre conceitos e serviços do TBC. Como observado por Sharpley (2014), pesquisas com a intenção de identificar e explicar a percepção e o relacionamento entre comunidades locais e turistas raramente consideram o estudo da relação visitante-visitado (Smith, 1999).

O segundo estudo contempla uma pesquisa qualitativa que explora e analisa a atual cadeia produtiva de TBC na favela Santa Marta. Com base nos resultados do primeiro estudo, foram realizadas entrevistas semies truturadas em novas visitas à favela, com a intenção de esclarecer alguns tópicos e aprofundar conceitos relacionados às percepções dos moradores que compõem aquela rede de TBC. Como observado por Woosnam (2012, p. 315), "a literatura atual sobre o TBC não registra como se sentem os residentes a respeito das atividades turísticas, em nível individual". Buscando eliminar essa lacuna, esta pesquisa procurou captar e compreender opiniões pessoais dos atores sociais envolvidos com o TBC na favela Santa Marta.

Por fim, propõe-se um debate sobre os resultados obtidos e a problematização de discussões com a intenção de se fomentar a continuidade de pesquisas no âmbito da temática do Turismo em Favelas e Turismo de Base Comunitária.

\section{TURISMO EM FAVELAS: OPORTUNIDADE OU OPORTUNISMO?}

Embora o turismo no Brasil, e principalmente no Rio de Janeiro, esteja relacionado às praias tropicais, ao carnaval e ao samba (Freire-Medeiros, 2009), uma imagem negativa do país também é percebida em nível internacional, vinculada à criminalidade e ao tráfico internacional de drogas, sobretudo nas favelas da cidade do Rio de Janeiro (Carvalho \& Silva, 2012). Apesar disso, é correto afirmar que a atratividade turística das favelas se tornou um novo fenômeno na cidade (Freire-Medeiros, 2009).

Como já apontado, o crescimento dessa atratividade foi acompanhado por discussões e debates em relação aos motivos éticos que provocam tal interesse turístico. Freire-Medeiros (2009) considera natural que a criação de uma mercadoria a partir daqueles locais possa provocar conflitos sociais, éticos e morais. Segundo alguns autores, por mais que sua intenção seja contribuir, os visitantes não sabem exatamente qual é o impacto final dessas atividades sobre os moradores das favelas turistificadas (Freire-Medeiros, 2009; Ma, 2010).

Em relação ao desenvolvimento dos roteiros nominados como favela tours, alguns autores apontam que inicialmente a experiência oferecida aos turistas se reduzia à observação da vida e do trabalho cotidiano das favelas. Estudos apontam que essas atividades podem se configurar como mercantilização da pobreza, que ocorre quando o intermediário turístico externo produz experiência de forma a melhor atender seus interesses, espetacularizando o ambiente de con- 
traste social da favela (Cejas, 2006; Klepsch, 2010).

Ao observar tais impactos negativos em relação ao seu local de convívio, alguns moradores de áreas urbanas classificadas como favelas turísticas (Freire-Medeiros et al., 2013) começaram a se organizar para oferecer roteiros mais coerentes com suas realidades e valores, proporcionando aos visitantes experiências que propõem a desconstrução de estereótipos e mostram a diversidade local (Rodrigues, 2014) . Essa operacionalização protagonizada pela comunidade local é norteada pelos conceitos fundamentais do TBC (Bursztyn \& Bartholo, 2012).

\section{TURISMO DE BASE COMUNITÁRIA - TBC}

Para se compreender melhor o que é TBC, deve-se considerar que não existe uma conceituação consensual para o termo, visto que ele emerge de diversos campos teóricos. O TBC não representa apenas mais um segmento de mercado, mas a possibilidade de um novo paradigma, uma forma mais responsável de se planejar e executar a experiência turística em áreas menos privilegiadas do ponto de vista dos indicadores econômicos e da oferta de infraestrutura urbana básica (Machado, 2007; Irving, 2009; Fabrino, 2013).

Ressalta-se que no TBC as relações econômicas são enriquecidas por outros elementos que transcendem a racionalidade do lucro imediato (Fabrino, 2013) e garantem alguma contribuição para o processo de valorização da identidade e pertencimento local, do modo de vida e do bem-estar socioeconômico das populações por meio do relaciona- mento entre turistas e moradores (Sansolo \& Bursztyn, 2009).

Nesse sentido, o objetivo principal do TBC está relacionado ao desenvolvimento local em longo prazo, baseado em modelo socialmente mais justo e duradouro. Tal estratégia compreende o turismo não apenas como objeto de lucro nas mãos de poucos operadores e empresários, mas como conjunto de atividades que podem ser benéficas para muitos outros atores sociais (Machado, 2007; Rodrigues, 2014; Catão, 2014).

Diante desse cenário, Nunkoo e Gursoy (2012) ressaltam a importância para pesquisadores, acadêmicos e demais atores sociais de entender o suporte da comunidade como um componente do desenvolvimento do turismo sustentável em comunidades. Fabrino (2013) reitera que um dos grandes diferenciais dessa forma de se propor o desenvolvimento do turismo recai justamente na possibilidade de o turista conhecer e interagir com as dinâmicas comunitárias, a partir do estabelecimento de uma relação dialógica entre visitantes e visitados, sendo o diálogo, o reconhecimento do outro, a troca e o compartilhamento de vivências a base desse encontro.

\subsection{Turismo de Base Comunitária em Favelas}

É fundamental reconhecer que o fenômeno turístico se constitui basicamente do encontro de alteridades que podem produzir processos de aculturação mais ou menos intensos, porém inevitáveis. De acordo com Garcia, Macía \& Vazques (2015), no plano sociocultural, interações que envolvem visitante e visitado podem resultar em novas 
oportunidades sociais e culturais ou gerar sentimentos de aflição, pressão e incômodo, ameaçando a identidade local e a realidade social dos moradores.

Alguns estudos relacionaram o TBC ao Turismo em Favelas. Spampinato (2009) concluiu seu trabalho realizado na favela da Rocinha, no Rio de Janeiro, afirmando que é possível pensar a atividade turística de forma integrada ao território de favelas, incluindo e beneficiando a comunidade local nos seus arranjos produtivos. A autora entende que, se o turismo for planejado de maneira adequada, as atividades geradas podem servir de estímulo para a valorização socioeconômica e cultural das favelas (Spampinato, 2009).

Ao refletir sobre os roteiros favela tour, a autora aponta que no momento de seu estudo as atividades turísticas não eram satisfatórias para a comunidade, para suas lideranças e tampouco para seus moradores (Spampinato, 2009). Vale observar que aqueles roteiros mais reconhecidos e populares são realizados em veículos tipo jipe militar, que percorrem as principais ruas das favelas e param em locais previamente determinados por agentes externos à favela visitada (Rodrigues, 2014). Segundo esse modelo de tour, as vielas da favela, potenciais locais de encontros, construções sociais e subjetivas, são reduzidas a um simples cenário de observação para os turistas e algumas poucas trocas econômicas (Machado, 2007). Como resultado da experiência oferecida, o turista é levado a enxergar o morador como um representante da pobreza, enquanto o morador, por sua vez, percebe o visitante como um representante da oportunidade de se ganhar algum dinheiro.
$O$ anseio por vivenciar novas experiências, e não apenas usufruir de novos produtos e serviços ou observar coisas novas, nos leva a registrar a presença de uma nova característica na demanda turística. Está ocorrendo uma mudança gradual no interesse dos visitantes, que passam a valorizar aspectos específicos da cultura dos lugares visitados em detrimento dos ícones culturais (SNV, 2009 apud Bursztyn \& Bartholo, 2012).

\subsection{Turismo de Base Comunitária na Favela Santa Marta (RJ)}

Talvez uma das favelas turísticas mais conhecidas do Rio de Janeiro seja a Santa Marta, localizada no bairro de Botafogo, Zona Sul da cidade. Povoado inicialmente por volta de 1930, o território de 50.000 metros quadrados é atualmente habitado por cerca de 5.000 pessoas (Freire-Medeiros, Vilarouca \& Menezes, 2012). Sua popularização no mercado turístico deu-se principalmente após a gravação do clipe They don't care about us, do cantor americano Michael Jackson (Freire-Medeiros et al., 2012), ainda que as autoridades locais da época tenham se posicionado contra a atitude do artista de gravar na favela, apontando que o videoclipe denegriria a imagem do Rio de Janeiro. Passados alguns anos, percebeu-se o potencial turístico gerado, e o local da gravação foi refuncionalizado como espaço temático do artista (Rodrigues, 2014).

Em 2010, o programa Rio Top Tour, organizado pelo governo do Estado do Rio de Janeiro, foi o primeiro projeto público de TBC em uma favela. Aquela proposta buscava promover avanços no turismo local, definin- 
nindo que as atividades passariam a ser conduzidas pela própria comunidade do Santa Marta. Apesar de o projeto ter sido interrompido precocemente pelo poder público, ainda é possível observar alguns de seus legados: o desenvolvimento de atrativos e de profissionais de turismo, o esclarecimento da população local sobre o TBC e a formação de opiniões de moradores sobre o turismo na favela.

O fato é que as atividades turísticas promovidas pela comunidade se tornaram realidade cotidiana naquele território (Rodrigues, 2014). Atualmente, cerca de 20 profissionais compõem o Comitê de Guias de Turismo do Santa Marta, e as empresas que tradicionalmente promoviam atividades turísticas em jipes já não prestam esses serviços na favela (Rodrigues, 2014).

Aponta-se que o desenvolvimento da demanda turística na favela Santa Marta também foi beneficiado pelo projeto das UPPs, novo modelo de policiamento que envolve o monitoramento constante de morros cariocas por meio da realização de abordagens policiais periódicas, do uso de câmeras de vigilância instaladas em vários pontos e de diferentes ferramentas de aproximação entre moradores e policiais (Menezes, 2014).

Os resultados do projeto Rio Top Tour possibilitam observar como o sentido comunitário e de pertencimento local foi estimulado e impulsionado pela atividade de TBC, por meio da qual o morador encontra seu espaço livre de expressão e busca cada vez mais assumir o papel de protagonista dos arranjos turísticos nas favelas (Spampinato, 2009; Rodrigues, 2014).

\section{METODOLOGIA}

A pesquisa foi produzida com base em abordagem multimétodos, com adoção de uma fase preliminar quantitativa e, em seguida, uma fase investigativa qualitativa destinada ao aprofundamento das questões e ao enriquecimento da visão sobre o fenômeno estudado, seguindo a recomendação da literatura de que estudos quantitativos são limitados e nem sempre os mais adequados para a compreensão de contextos de alta complexidade, como é o caso do turismo. A combinação de métodos amplia as possibilidades de reflexão (Creswell, 2007).

O estudo quantitativo teve o objetivo de desenvolver comparação entre as percepções de moradores e visitantes em relação às atividades turísticas praticadas na favela Santa Marta, assim como conhecer as motivações dos turistas para visitar o local. Uma pesquisa do tipo survey foi aplicada entre os dias 17 e 29 de abril de 2015 a uma amostra não probabilística de 80 moradores e 80 turistas na favela. Para a aplicação da pesquisa entre os turistas, foi montado um posto de coleta na laje Michael Jackson, local de maior atratividade turística da favela.

O questionário da pesquisa quantitativa foi dividido em quatro seções: a) perfil do entrevistado; b) percepções gerais sobre o turismo na favela, capturadas por meio do procedimento free elicitation (Oleary \& Deegan, 2005; Figueiredo e Mayer, 2010); c) motivações do turista, com uso das categorias motivacionais testadas por Ma (2010) na região de Dharavi, Índia; d) percepções específicas relacionadas ao turismo de base comu- 
nitária, como vantagens e desvantagens econômicas, impactos socioculturais, segurança pública e relacionamento entre turistas e moradores.

A escala de motivações do estudo de Ma (2010) foi traduzida para o português, e os itens foram adaptados aos objetivos do estudo por uma banca formada por dois especialistas seniores. A escala consistiu em 21 afirmações relacionadas a seis categorias motivacionais: curiosidade cultural, interesse próprio, outros tipos de curiosidades, escapismo, conexão com experiências não turísticas e preconceitos sobre turismo em favelas. Foi utilizada uma escala Likert de cinco pontos para permitir que os respondentes expressassem seu grau de concordância com os itens das escalas de motivações e percepções (Corrar, Paulo \& Filho, 2012). Os cinco pontos refletem a força e a direção da reação do entrevistado e foram traduzidos em: discordo totalmente, discordo parcialmente, não concordo nem discordo, concordo parcialmente, concordo totalmente. Os dados foram tratados no software estatístico SPSS
(Statistical Package for the Social Sciences), versão 23.0.

No segundo estudo, de caráter qualitativo, foram realizadas entrevistas em profundidade, no período de 21 a 28 de setembro de 2015, com participantes da cadeia produtiva do TBC da favela Santa Marta. Discrepâncias de opiniões entre turistas e moradores, reveladas no estudo quantitativo, foram utilizadas para a formulação de um roteiro semiestruturado para as entrevistas. Adicionalmente, foram desenvolvidos questionamentos com base em resultados que despertaram discussões relacionadas à revisão bibliográfica.

Para a etapa qualitativa do estudo, foram selecionados agentes de diferentes áreas de envolvimento da cadeia local de TBC da favela Santa Marta. Entre eles incluíramse guias de turismo locais, produtores culturais, empreendedores, proprietários e funcionários de comércios que se apropriaram do fluxo de turistas, além do presidente da Associação de Moradores da Comunidade Santa Marta (Quadro 1).

\begin{tabular}{cc} 
Quadro 1-Descrição dos entrevistados da cadeia de TBC \\
\hline Entrevistado 1 & Guia, produtor cultural e empreendedor \\
Entrevistado 2 & Guia, produtor cultural e empreendedor \\
Entrevistado 3 & Guia e empreendedora \\
Entrevistado 4 & Guia e empreendedora \\
Entrevistado 5 & Intérprete de idiomas em roteiros turísticos \\
Entrevistado 6 & Atendente de loja de suvenires \\
Entrevistado 7 & Proprietário de loja de suvenires \\
Entrevistado 8 & Proprietário de restaurante \\
Entrevistado 9 & Presidente da associação de moradores
\end{tabular}

Fonte: Elaborado pelos autores

As entrevistas tiveram duração média de uma hora e foram transcritas para possi- bilitar análise criteriosa das informações obtidas, seguindo procedimento de análise de 
conteúdo, baseado na categorização e interpretação de acordo os seguintes tópicos: relacionamento visitante $\mathrm{x}$ visitado; papel dos guias locais; experiência dos visitantes; protagonismo dos moradores; futuro do TBC na favela; amadurecimento da cadeia do TBC.

\section{ESTUDO QUANTITATIVO: COMPARANDO AS PERCEPÇÕES DE MORADORES E TU- RISTAS}

Analisando os dados obtidos e distinguindo moradores e visitantes, pode-se dizer que nos dois casos houve distribuição equilibrada de gênero entre os entrevistados, sendo $52,5 \%$ dos moradores e $56,3 \%$ dos visitantes do sexo feminino. Em relação à idade, a maior parte dos moradores tem mais de 60 anos (22,5\%), seguida daqueles que declaram ter entre 25 a 29 anos (16,2\%) e entre 40 a 49 anos (16,2\%). Na amostra de turistas, a maior parte dos indivíduos declarou ter idade entre 25 e 39 anos (65,0\%).

Em referência ao local de origem dos visitantes, pode-se observar que a maior parte dos turistas entrevistados são oriundos da Europa (46\%), seguidos por pessoas residentes no Brasil (21\%), América do Norte/Central (14\%) e América do Sul (10\%). Essa informação confirma a predominância de turistas do hemisfério Norte interessados pelas favelas, conforme é apontado por Cejas (2006).

Considerando a escolaridade, verificou-se diferença significativa entre os dois perfis. No grupo de moradores, quase metade da amostra declarou ter completado somente o ensino fundamental (45\%), e a outra metade, somente o ensino médio $(41,25 \%)$. Já no grupo de visitantes, quase metade cursou ensino superior $(41,25 \%)$, e uma parcela significativa, pós-graduação (28,75\%). Chama atenção a discrepância entre os níveis de escolaridade dos moradores e dos visitantes entrevistados, que pode ser interpretada como reflexo da condição social desses grupos. Dada a condição financeira desfavorecida que leva à necessidade de trabalhar e adquirir renda, muitos moradores de favelas são levados a interromper os estudos de forma precoce (Gaffney, 2013).

\subsection{Percepções Gerais Sobre o Turismo}

Para o procedimento free elicitation, turistas e moradores foram estimulados a dizer as três primeiras palavras que vinham à mente quando pensavam na expressão "Turismo em Favela". A análise do resultado obtido foi feita por meio de duas word clouds, com uso da plataforma online wordle (http://www.wordle.net), representando as percepções de cada um dos grupos.

Observando as palavras fornecidas pelos moradores (Figura I), destacam-se "curiosidade", "conhecimento", "conhecer" e "diversão". Percebe-se que, na visão dos moradores, esses podem ser os motivos que levam os turistas a se interessar pelas visitas às favelas. Entretanto, é importante notar que há palavras com menor destaque que se referem a sentimentos negativos em relação ao turismo na favela, como "indiferente,", "desigualdade" e "vergonha". 
Figura 1 - Percepções dos moradores em relação ao turismo em favelas

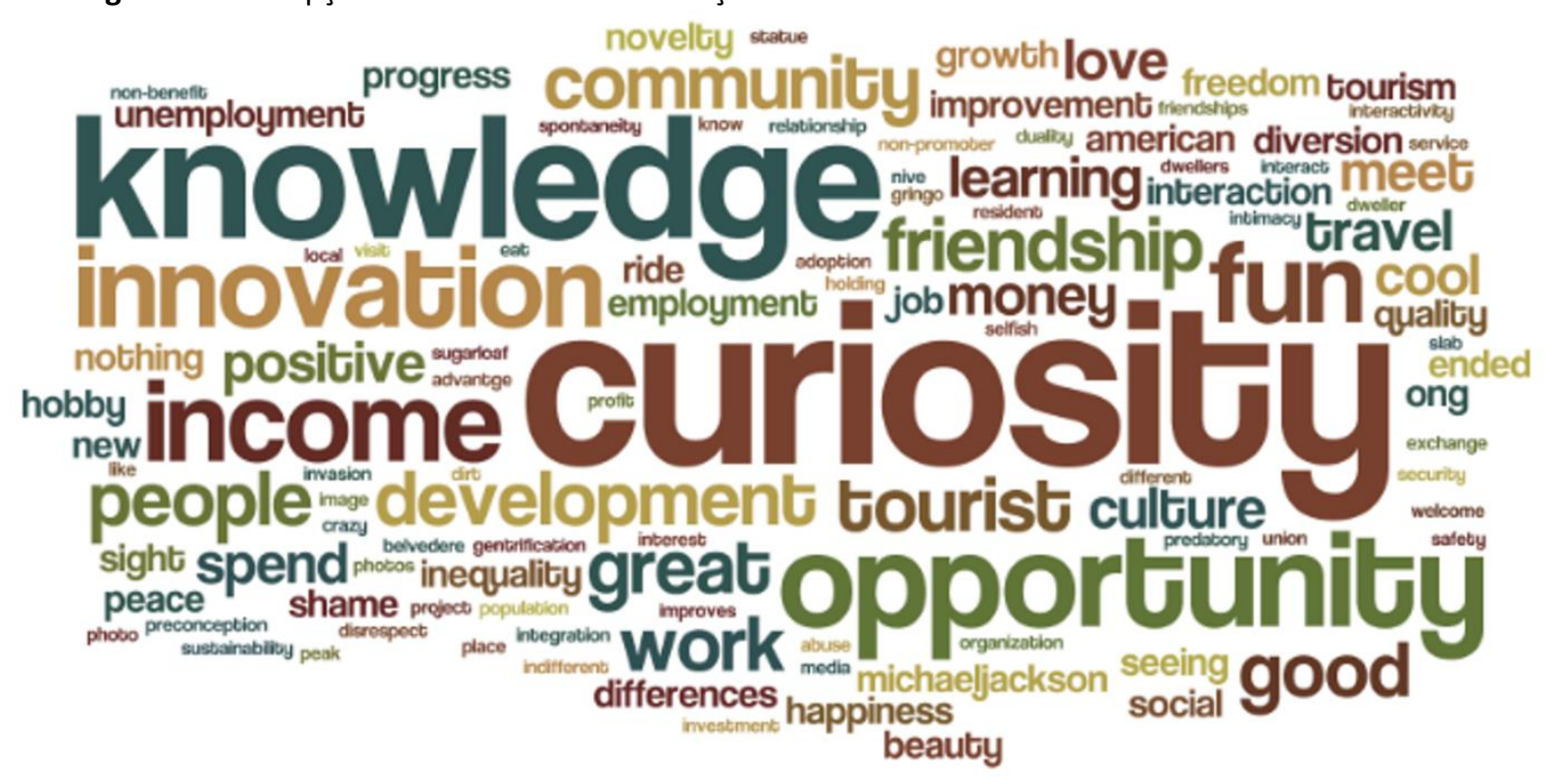

Fonte: Elaborado pelos autores

Também chama a atenção que, dentre as diversas respostas, destaca-se a palavra "oportunidade", o que indica que alguns moradores relacionam o "Turismo em Favela" a interesses e possibilidades de renda. Esse dado reitera o que Rodrigues (2014) afirma sobre o crescente esclarecimento dos moradores acerca de oportunidades que podem provir das atividades relacionadas ao TBC.

Na word cloud construída com as palavras citadas pelos visitantes, "interessante" aparece com grande destaque, além de "cultura", "curiosidade", "diferente", "esclarecedor" e "pessoas". Em geral, essas palavras se referem à curiosidade cultural e local, além do sentimento de surpresa quando o visitante descobre que a favela é diferente do que ele esperava encontrar. No entanto, um olhar mais atento possibilita observar palavras que se relacionam com o contraste e o estereótipo social das favelas, como "pobre" (poor), "pobreza" (poverty) e "perigo" (danger). 
Figura 2 - Percepções dos turistas em relação ao turismo em favelas

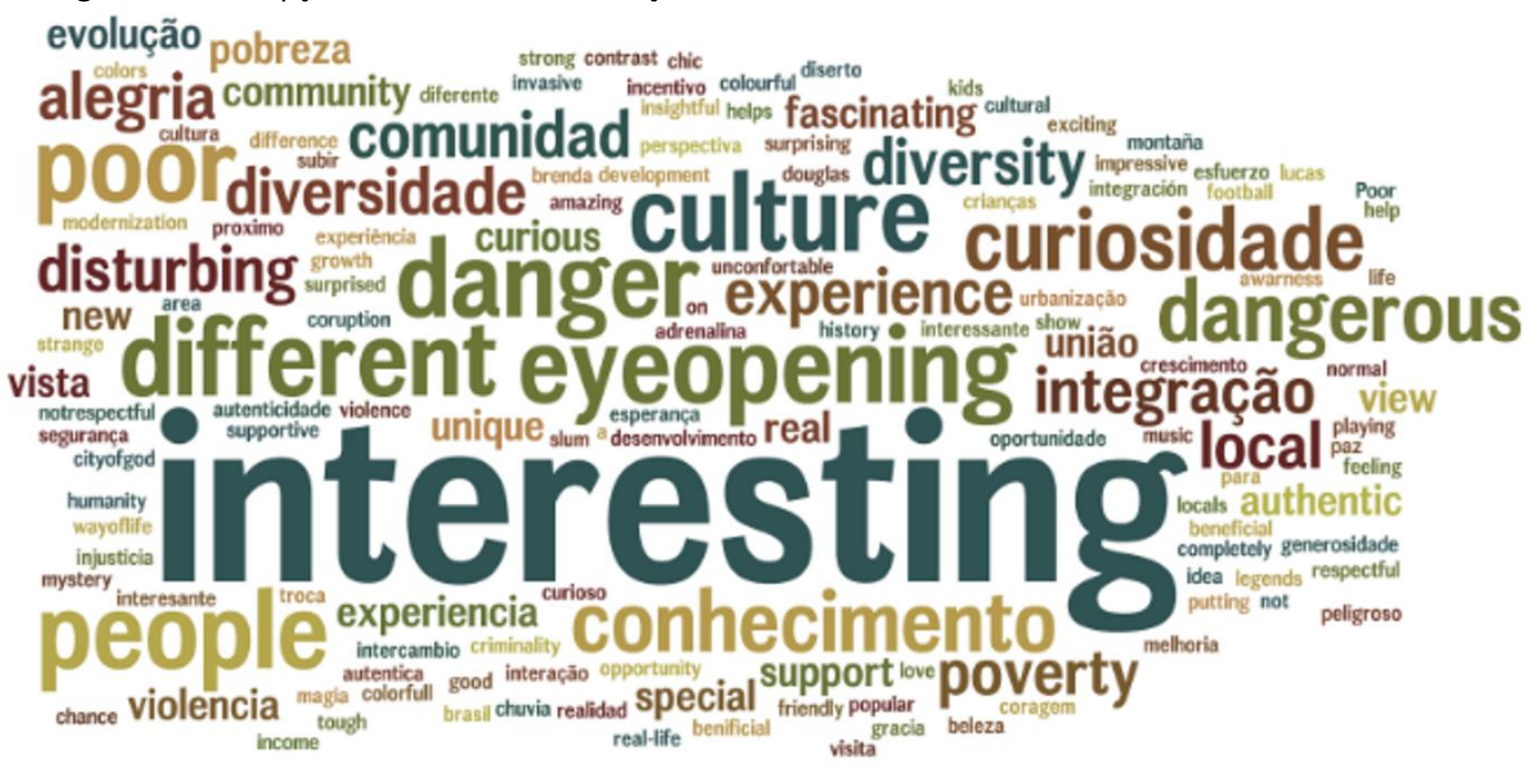

Fonte: Elaborado pelos autores

Essas palavras estão de acordo com a análise de Freire-Medeiros (2009) no que se refere à busca de turistas por lugares diferentes dos roteiros tradicionais. Ainda que a pobreza chame a atenção, a visita é de alguma maneira esclarecedora e interessante por outros motivos para esses visitantes.

\subsection{Motivações do Turismo em Favela eTBC}

A Tabela 1 retrata a comparação entre as percepções de moradores e turistas em relação aos fatores que motivam o turismo em favelas e fatores relacionados ao TBC nessas comunidades. Para verificar a existência de diferenças estatisticamente significativas, foi usada análise de variância (ANOVA), que testa a hipótese de que as médias de duas ou mais populações são iguais. O nível de significância escolhido foi de 0,05, com intervalo de confiança de $95 \%$ (Hair et al., 1998).

Foram encontradas diferenças significativas entre a opinião de moradores e turis- tas em onze itens do questionário, que merecem análise mais cuidadosa. Em todos os casos, a opinião de moradores e de turistas caminhou na mesma direção, mas com diferenças na intensidade com que concordaram com as motivações para o turismo em favelas.

Na categoria "curiosidade cultural", os turistas concordaram de forma mais intensa (média $=4,68$ ) do que os moradores (média $=4,49$ ) que a "curiosidade em ver um modo de vida diferente" é a principal motivação para esse tipo de turismo. Já na categoria "outras curiosidades", os turistas indicaram maior grau de concordância com todos os itens, indicando com mais intensidade que desejam "ver de perto as controvérsias do turismo em favela". No aspecto "vontade de interagir com os moradores das favelas", moradores concordaram menos (média $=3,24$ ) com a afirmação do que turistas (média = 3,61 ), um possível reflexo de experiências vividas anteriormente. 
Tabela 1 - Diferenças entre as percepções de moradores e turistas

\begin{tabular}{|c|c|c|c|c|}
\hline Categoria Motivacional - Curiosidade Cultural & $\begin{array}{l}\text { Médias } \\
\text { Mora- } \\
\text { dores }\end{array}$ & $\begin{array}{c}\text { Médias } \\
\text { Tu- } \\
\text { ristas }\end{array}$ & $\mathbf{F}$ & sig \\
\hline Curiosidade em ver um modo de vida diferente. & 4,49 & 4,68 & 5,822 & $0,017 *$ \\
\hline $\begin{array}{l}\text { Ver o cenário, as vielas e a vista da cidade que se } \\
\text { tem em uma favela. }\end{array}$ & 4,35 & 4,31 & 0,065 & 0,799 \\
\hline $\begin{array}{l}\text { Pensar que a visita retrata a vida na favela de forma } \\
\text { autêntica. }\end{array}$ & 4,00 & 3,99 & 3,067 & 0,082 \\
\hline $\begin{array}{l}\text { Fugir um pouco dos passeios mais tradicionais da ci- } \\
\text { dade. }\end{array}$ & 4,20 & 4,10 & 0,14 & 0,708 \\
\hline $\begin{array}{l}\text { Experimentar a vida em um ambiente de extrema po- } \\
\text { breza. }\end{array}$ & 3,15 & 3,08 & 3,587 & 0,060 \\
\hline Categoria Motivacional - Outras Curiosidades & $\begin{array}{l}\text { Médias } \\
\text { Mora- } \\
\text { dores }\end{array}$ & $\begin{array}{l}\text { Médias } \\
\text { Tu- } \\
\text { ristas }\end{array}$ & $\mathbf{F}$ & sig \\
\hline $\begin{array}{l}\text { Vontade de contribuir para o bem-estar dos morado- } \\
\text { res das favelas. }\end{array}$ & 3,10 & 3,79 & 25,283 & $\mathbf{0 , 0 0 0 *}$ \\
\hline Ver de perto as controvérsias do turismo em favela. & 3,75 & 3,89 & 10,794 & $\mathbf{0 , 0 0 1 *}$ \\
\hline Vontade de interagir com os moradores das favelas. & 3,24 & 3,61 & 13,614 & $0,000 *$ \\
\hline Categoria Motivacional - Interesse próprio & $\begin{array}{l}\text { Médias } \\
\text { Mora- } \\
\text { dores }\end{array}$ & $\begin{array}{c}\text { Médias } \\
\text { Tu- } \\
\text { ristas }\end{array}$ & $\mathbf{F}$ & sig \\
\hline $\begin{array}{l}\text { Pensar que um passeio pelas favelas é uma experiên- } \\
\text { cia única e inesquecível. }\end{array}$ & 3,89 & 4,36 & 7,96 & $0,005 *$ \\
\hline $\begin{array}{l}\text { Ver o contraste entre o lado rico e o lado pobre do } \\
\text { Rio de Janeiro. }\end{array}$ & 4,16 & 4,07 & 8,465 & $\mathbf{0 , 0 0 4} *$ \\
\hline $\begin{array}{l}\text { Curiosidade para saber como é sua própria vida em } \\
\text { comparação com a de moradores da favela. }\end{array}$ & 3,94 & 3,79 & 0,327 & 0,568 \\
\hline $\begin{array}{l}\text { Vontade de valorizar mais a própria vida após a vi- } \\
\text { sita. }\end{array}$ & 3,87 & 3,50 & 0,02 & 0,889 \\
\hline Categoria Motivacional - Escapismo & $\begin{array}{l}\text { Médias } \\
\text { Mora- } \\
\text { dores }\end{array}$ & $\begin{array}{l}\text { Médias } \\
\text { Tu- } \\
\text { ristas }\end{array}$ & $\mathbf{F}$ & sig \\
\hline Pensar que o passeio é divertido e emocionante. & 3,91 & 3,63 & 0,804 & 0,371 \\
\hline Fugir um pouco da vida na cidade. & 3,64 & 3,54 & 7,827 & 0,006* \\
\hline $\begin{array}{l}\text { Categoria Motivacional - Conexão com experiên- } \\
\text { cias não turísticas }\end{array}$ & $\begin{array}{l}\text { Médias } \\
\text { Mora- } \\
\text { dores }\end{array}$ & $\begin{array}{l}\text { Médias } \\
\text { Tu- } \\
\text { ristas }\end{array}$ & $\mathbf{F}$ & sig \\
\hline $\begin{array}{l}\text { Vontade de compartilhar a experiência com sua fa- } \\
\text { mília e seus amigos depois. }\end{array}$ & 4,02 & 4,20 & 1,776 & 0,185 \\
\hline $\begin{array}{l}\text { Acredito que depois do passeio os turistas fiquem } \\
\text { mais interessados sobre a vida das pessoas que pas- } \\
\text { sam necessidade e procurem entender melhor sobre } \\
\text { as condiçoes em que elas vivem. }\end{array}$ & 3,59 & 3,88 & 13,009 & $\mathbf{0 , 0 0 0 *}$ \\
\hline $\begin{array}{l}\text { Curiosidade depois de conhecer o turismo em favelas } \\
\text { através de diversas mídias. }\end{array}$ & 4,21 & 3,90 & 7,214 & $0,008^{*}$ \\
\hline $\begin{array}{l}\text { Ver a favela que somente conhecia através de filmes } \\
\text { e livros. }\end{array}$ & 4,2 & 3,84 & 0,603 & 0,438 \\
\hline
\end{tabular}


Tabela 1 - Diferenças entre as percepções de moradores e turistas

\begin{tabular}{|c|c|c|c|c|}
\hline $\begin{array}{l}\text { Categoria Motivacional - Preconcepções do tu- } \\
\text { rismo em favela }\end{array}$ & $\begin{array}{l}\text { Médias } \\
\text { Mora- } \\
\text { dores }\end{array}$ & $\begin{array}{c}\text { Médias } \\
\text { Tu- } \\
\text { ristas }\end{array}$ & $\mathbf{F}$ & sig \\
\hline $\begin{array}{l}\text { Mudar a imagem negativa das favelas que as pessoas } \\
\text { têm em mente. }\end{array}$ & 3,64 & 4,26 & 25,793 & $0,000 *$ \\
\hline $\begin{array}{l}\text { A vida na favela parece mais autêntica e genuína do } \\
\text { que a vida na cidade. }\end{array}$ & 3,83 & 3,49 & 4,271 & $0,040 *$ \\
\hline Ver um tipo diferente de pobreza. & 3,80 & 3,37 & 0,389 & 0,534 \\
\hline TBC em Favelas & $\begin{array}{l}\text { Médias } \\
\text { Mora- } \\
\text { dores }\end{array}$ & $\begin{array}{l}\text { Médias } \\
\text { Tu- } \\
\text { ristas }\end{array}$ & $\mathbf{F}$ & sig \\
\hline $\begin{array}{l}\text { O turismo pode trazer vantagens econômicas para as } \\
\text { favelas e empreendedores locais, como a geração de } \\
\text { empregos e renda. }\end{array}$ & 3,64 & 4,41 & 15,694 & $0,000 *$ \\
\hline $\begin{array}{l}\text { Projetos sociais e ONGs locais deveriam ser benefici- } \\
\text { ados pelas visitas turísticas. }\end{array}$ & 4,45 & 4,26 & 1,719 & 0,192 \\
\hline $\begin{array}{l}\text { A interação que ocorre entre os moradores das favelas } \\
\text { e os turistas é positiva. }\end{array}$ & 3,83 & 4,21 & 4,631 & $\mathbf{0 , 0 3 3} *$ \\
\hline $\begin{array}{l}\text { O turismo em favelas pode contribuir com o desenvol- } \\
\text { vimento social local por meio da organização de seus } \\
\text { moradores. }\end{array}$ & 4,05 & 4,37 & 3,296 & 0,071 \\
\hline $\begin{array}{l}\text { O turismo pode trazer desvantagens econômicas para } \\
\text { as favelas, como aumento do custo de vida e especu- } \\
\text { lação imobiliária. }\end{array}$ & 3,00 & 2,86 & 0,389 & 0,534 \\
\hline
\end{tabular}

$\mathrm{O}$ item que parece indicar menor alinhamento entre a opinião dos dois grupos é a motivação para "contribuir para o bem-estar dos moradores das favelas". Moradores se mostraram menos otimistas e convictos em relação a essa ideia (média $=3,10$ ) do que turistas $(3,79)$. Na categoria "interesse próprio", moradores (média $=3,89$ ) indicaram menor grau de concordância do que turistas (média=4,36) com a ideia de que "um passeio pelas favelas é uma experiência única e inesquecível". Mas moradores (média=4,16) indicaram maior concordância do que turistas (média $=4,07$ ) com a afirmação de que o turismo busca "ver o contraste entre o lado rico e o lado pobre do Rio de Janeiro".

Já na categoria "escapismo", moradores indicaram maior grau de concordância (média $=3,64$ ) com a motivação "fugir um pouco da vida na cidade" do que os turistas (média $=3,54$ ). Na categoria "conexão com experiências não turísticas", os visitantes concordaram em menor grau (média $=3,90$ ) do que os moradores (média $=4,20$ ) que o desejo de ir à favela apareceu "depois de conhecer o turismo em favelas através de diversas mídias", indicando que os visitantes podem não estar tão motivados por esse quesito quanto consideram os moradores entrevistados.

É importante ressaltar que moradores (média $=3,59$ ) se mostraram menos propensos a concordar que "depois do passeio os turistas fiquem mais interessados sobre a vida das pessoas que passam necessidade" do que os próprios turistas (média $=3,88$ ). Na última categoria motivacional, "preconcepções do turismo em favela", as opiniões de mora- 
dores e turistas são significativamente diferentes quanto à motivação para o turismo em favela estar relacionado a uma possível vontade de "mudar a imagem negativa das favelas que as pessoas têm em mente". Nesse aspecto, moradores se revelaram mais descrentes (média=3,64) do que turistas (média=4,26).

Por fim, os moradores (média $=3,83$ ) tenderam a concordar mais do que os turistas (média $=3,49$ ) com a ideia de que o turismo em favela é uma busca por uma "vida [...] mais autêntica e genuína do que a vida na cidade".

Em relação às percepções sobre TBC na favela, houve diferença significativa de opinião entre moradores e turistas em dois itens relevantes. Em primeiro lugar, moradores (média $=3,64$ ) concordaram em menor grau do que visitantes (média $=4,41$ ) que "o turismo pode trazer vantagens econômicas para as favelas e empreendedores locais, como a geração de empregos e renda". Em segundo lugar, visitantes (média $=4,21$ ) tenderam a concordar mais do que moradores (média=3,83) que "a interação que ocorre entre os moradores das favelas e os turistas é positiva". Isso pode ser justificado pelo histórico das visitas turísticas e pelo imaginário geral da comunidade sobre o turismo em favelas, muito marcado por estereótipos, preconceitos e generalizações.

Merece ainda destaque o fato de que tanto moradores quanto turistas apresentaram baixo grau de concordância $(3,00$ e 2,86) com a afirmação de que "o turismo pode trazer desvantagens econômicas para as favelas, como aumento do custo de vida e especulação imobiliária", indicando uma tendên- cia à subestimação dos efeitos negativos do turismo entre os entrevistados.

A análise desses resultados originou outras discussões fundamentadas principalmente pela ideia de que as atividades de TBC em favelas podem ser identificadas como tentativas de reinvenção da atividade turística, com base em premissas que tornem a atividade crítica e reflexiva (Klepsch, 2010) e proporcionem conhecimento e interações entre pessoas que dificilmente se encontrariam se não fosse pelo turismo (Freire-Medeiros, 2009). Entre tais resultados discutidos estão os impactos socioeconômicos das atividades turísticas nas favelas, a diferença de percepção nas atividades promovidas por agentes locais e as opiniões sobre o momento atual e o futuro dessas atividades turísticas.

\section{ESTUDO QUALITATIVO: ANÁLISE DA CA- DEIA DE TURISMO COMUNITÁRIO DA FA- VELA SANTA MARTA}

Com base na análise das percepções dos moradores e dos turistas, foi realizado um estudo qualitativo. $O$ objetivo foi buscar compreender de forma mais aprofundada a realidade do TBC na favela Santa Marta e refletir sobre questões que envolveram as diferenças entre os grupos que foram encontradas no estudo quantitativo.

As respostas das entrevistas demonstram que o envolvimento dos entrevistados com as atividades turísticas na favela ocorreu, de forma geral, a partir do período de início do projeto Rio Top Tour, em 2008. Podese concluir que a existência daquele projeto incentivou muitos moradores da favela Santa 
Marta a dedicar seu tempo, de maneira integral ou parcial, às atividades turísticas. Apesar da existência de atividades relacionadas ao turismo anteriormente a esse período, pode-se afirmar que em 2008 foi desencadeado o processo de formação da rede de TBC que é analisada neste estudo.

Durante a análise dos resultados, percebeu-se que os atores sociais entrevistados possuem percepções críticas em relação a diversos aspectos dos impactos do turismo, sendo estes principalmente os socioeconômicos e culturais. Irving (2009) mostra que a condição essencial para ocorrer o TBC é o encontro entre alteridades, no sentido de compartilhamento e aprendizagem mútua entre os participantes. Sansolo \& Bursztyn (2009) indicam a valorização da identidade cultural, além da conservação ambiental e da geração de benefícios diretos para as comunidades receptoras como componentes sustentadores do TBC. A síntese do presidente da associação de moradores faz referência a essas questões quando reflete sobre o que mudou na favela a partir do início das atividades turísticas:

O turismo traz na sua bagagem o empreendedorismo, a empregabilidade, além de descortinar a favela para o mundo, mostrando suas especificidades, suas culturas. Acho que é positivo. (Entrevistado 9)

\subsection{Relacionamento Visitante $\mathrm{x}$ Visitado}

Um dos aspectos mais complexos no que se refere às atividades de turismo em favelas é o relacionamento interpessoal entre visitantes e moradores. As iniciativas de TBC trazem aos moradores maior sensação de proximidade com os turistas. Isso contribui com a desconstrução de opiniões baseadas em outros tipos de experiências de turismo em favelas, conforme apontado por um dos entrevistados:

Os moradores cumprimentam e falam com todos quando passam com os turistas, e isso gera integração. Isso faz acabar com aquela impressão de que o turismo faz da favela um zoológico. (Entrevistado 2)

A maneira como o tour é comercializado é determinante em relação ao perfil e à postura do turista que é atraído para visitar a favela. É essencial que a iniciativa local se assuma como agente ativo nas várias fases do processo de criação, implementação e gestão do projeto turístico (Spampinato, 2009). Ainda, a interação de moradores e turistas baseada em encontros genuínos é apontada como a principal ferramenta de aproximação:

Conosco o turista sai com uma vivência maior porque interagiu, conheceu a casa de um morador. Quando eu faço o tour eu interajo com a Dona Francisca, com a Dona Maria. Apertando a mão e me abraçando. Eles (os turistas) também interagem e percebem que realmente eu moro aqui e eu conheço todo mundo. Eles saem daqui com uma bagagem muito maior. (Entrevistado 4)

Guias e empreendedores locais revelaram que promovem ações nas quais revertem parte de seus lucros para moradores que não estão envolvidos com as atividades turísticas. Para isso, realizam festas e doações em datas comemorativas como Páscoa, Dia das Crianças e Natal. Também existe um acordo tácito segundo o qual todos se comprometem a contribuir com a Associação de Moradores. Segundo eles, essas ações levam os 
moradores que conhecem os impactos positivos do TBC passam a apoiar as atividades.

\subsection{O Papel dos Guias Locais}

A comparação do trabalho realizado pelos guias de turismo que são pertencentes à comunidade com o daqueles que vêm de outros locais possibilita afirmar que a favela é apresentada de maneira mais apropriada pelos primeiros devido à preocupação em se contar a história do local e das pessoas de maneira mais verdadeira. Para eles, isso contribui com a desconstrução de estereótipos e preconceitos que são reproduzidos por agentes externos, como guias que não são da favela e a mídia. Um guia de turismo aponta que guias externos apresentam as favelas em versão genérica e deixam de considerar peculiaridades:

O guia que vem de fora não sabe a história da comunidade. A mesma história que ele conta no Santa Marta ele conta na Rocinha, no Vidigal e ainda conta um monte de mentira. (Entrevistado 1)

Cabe aos guias locais realizar essa oferta de serviços da melhor maneira. O guia torna-se um ponto-chave nesse processo. Para o TBC, é importante que a presença do turista não cause estranhamento na favela. Dessa forma, quebram-se diversas barreiras entre visitantes e visitados:

Então ele (o guia) vai mostrar o lado positivo do projeto social, vai fazer feijoada na laje do Michael Jackson, vai entrar em contato com os moradores, e todos até vão comer juntos. Então eles sabem que são beneficiados com as visitas que a favela recebe, e é muito importante a gente mostrar o que a favela tem de bom. Não só o lado positivo, mas os problemas que tem, pras pessoas saberem que o lugar não é perfeito. (Entrevistado 5)

Portanto, a existência de uma rede de Turismo de Base Comunitária em uma favela tem o potencial de influenciar as impressões e perspectivas da comunidade e do próprio visitante. Muitos entrevistados afirmam que estão abertos a acordos de cooperação e parcerias com guias e empresas externas, para realizar serviços em conjunto na favela e promover a distribuição das atividades dentro de toda a comunidade. De acordo com um guia local:

O turista se sente bem com um guia local porque a gente conhece todo mundo. Fala com todo mundo, tira dúvida. Não tem pergunta que eu não consiga responder. $\mathrm{E}$ o fato de conhecer todo mundo e contar a história das pessoas. $\mathrm{O}$ acolhimento é outro, entendeu? (Entrevistado 3)

\subsection{A Experiência do Visitante}

Para motivar a participação da comunidade de modo que a atividade evolua de forma sustentável, deve-se estimular não o lucro, mas o empreendedorismo social e um turismo comunitário (Rodrigues, 2014).

Quando o impacto é minimizado por meio da participação de moradores locais como atores principais, os tours assumem funções positivas que influenciam diretamente as percepções dos turistas:

Ocorre a desmistificação de opiniões de pessoas que nunca estiveram em uma favela antes. (Entrevistado 1)

Depois do tour o turista percebe que a favela não é só o que a mídia mostra. (Entrevistado 5) 
Os entrevistados indicam que os turistas que buscam um tour "comunitário" têm uma postura muito mais respeitosa com os moradores. De acordo com uma guia local, também cabe aos guias e atores locais a instrução para uma boa postura por parte dos visitantes:

Quando é uma pessoa que não entende a proposta e porque as pessoas não gostam de fotos, eu só peço pra elas se colocarem no lugar do outro. Imagina se tem uma pessoa tirando foto de você nessa hora da manhã? Você vai gostar? (Entrevistado 3)

Sampaio e Coriolano (2009) afirmam que o diferencial do TBC recai justamente no entendimento de que a atividade turística está intimamente ligada a outras áreas, como educação, saúde e meio ambiente. Diante disso, a experiência do visitante é intrinsecamente modificada, porque o turismo comunitário não se centra somente na atividade turística, mas representa uma proposta de desenvolvimento territorial sustentável que abrange todos os envolvidos em diversas dimensões - política, cultural, econômica, humana.

\subsection{O Protagonismo dos Moradores}

A partir do momento em que moradores começam a protagonizar as atividades turísticas, o restante da comunidade passa a considerar diversas oportunidades no turismo. Isso inicia um processo de aceitação em relação às atividades turísticas. Como já apontado, de acordo com o tipo de atividade, os moradores passam a diferenciar seu comportamento em relação aos turistas e seus condutores dentro da favela:
Hoje a comunidade vê nosso trabalho com outros olhos. Nós somos os moradores das favelas que fazemos o turismo acontecer aqui dentro. Acho que a percepção do morador em relação a nós é positiva, mas ainda é negativa com as pessoas que vêm de fora. (Entrevistado 4)

Segundo os entrevistados, é crescente o interesse de moradores em se envolver diretamente com as atividades relacionadas ao turismo. Para as pessoas que já são participantes da cadeia de TBC, é de grande importância a participação do maior número possível de pessoas da comunidade. Entretanto, a qualidade do serviço também é um fator relevante:

Se o morador quiser ser ajudado, a gente está aí para ajudar. Nós somos experiências vivas superpositivas. Quer acompanhar a gente? Pode vir. Não é fechado. $O$ que a gente busca é a qualificação. (...) Se quiser guiar nós ajudamos com o curso de guia, o curso de monitor e toda a qualificação. (Entrevistado 1)

São citados exemplos de pessoas que trabalhavam em atividades relacionadas ao crime e ao tráfico e perceberam no turismo uma oportunidade de mudança de vida:

\footnotetext{
Hoje nós somos 20. Depois de mim outras pessoas vieram para mim e disseram "Eu preciso mudar de vida". Um é ex-presidiário que saiu da prisão e não queria mais aquela vida. Hoje em dia é um guia que trabalha e busca a qualificação. (Entrevistado 1)
}

A preocupação com a qualidade dos serviços é uma característica bastante relevante por se relacionar essencialmente aos estigmas que permeiam as favelas e seus moradores. Apesar do crescimento e da profissi- 
onalização das iniciativas comunitárias de turismo, existe grande desconfiança em relação a serviços relacionados à favela:

A gente tá igual formiguinha mudando esse panorama. Hoje eu já sou empresa, já participo de feiras de turismo, tenho minha logomarca. Acho que se falou em favela já tem preconceito. Então falou de empresa de favela... A gente tem que ser bom $200 \%$. Não pode ser $100 \%$. Ao primeiro erro a gente já sofre o preconceito. (Entrevistado 2)

\subsection{O Futuro do TBC na Favela}

O desenvolvimento do turismo na favela Santa Marta é frequentemente associado ao projeto das Unidades de Polícia Pacificadora (UPPs). Entretanto, considerando que esse projeto se insere no contexto político-social do Rio de Janeiro como cidadesede da Copa do Mundo de Futebol e das Olimpíadas, também estão associados a ele o surgimento de novas demandas de mercado, a especulação imobiliária, o aumento dos preços e a própria evasão de pessoas que perderam a possibilidade econômica de acompanhar o aumento dos aluguéis dentro da favela, por exemplo (Gaffney, 2013). O aumento dos preços na favela Santa Marta é uma realidade, e isso foi relacionado em diversos momentos à maior sensação de segurança que se estabeleceu ali, à localização estrategicamente positiva da favela e à própria movimentação turística:

Infelizmente os preços aumentam e as pessoas que vivem de aluguel são obrigadas a ir para outras favelas. Provavelmente outra favela que ainda é perigosa. (Entrevistado 6)
$\mathrm{O}$ aluguel realmente aumentou muito, mas até por causa da paz que você tem. Quem não quer morar na Zona Sul? (Entrevistado 7)

De acordo com o relato desses moradores, existe uma sensação de incertezas e insegurança em relação à estabilidade econômica na favela. Conforme aponta Menezes (2014), nos primeiros anos após a ocupação policial, havia um grande clima de incerteza em relação ao futuro:

O que pode vir a piorar pras comunidades, pros moradores principalmente, e pro comerciante e o turismo, é que todo mundo fala que depois das Olimpíadas vai enfraquecer a pacificação. Que vai diminuir o número de polícia. Que estão fazendo isso só pra favela ser um cartãopostal. (Entrevistado 7)

O enfraquecimento do projeto das UPPs já se mostrava perceptível durante o momento de realização desta pesquisa. A redução do ritmo do processo de pacificação das favelas era um sintoma claro:

Você vê que pacificavam sempre. Era uma atrás da outra. Agora não estão mais pacificando nada. Seguraram a onda. (Entrevistado 8)

$\mathrm{Na}$ atualidade, com a crise econômica, social e política que o estado do Rio de Janeiro enfrenta, o projeto das UPPs encontra-se em um momento de revisão, dado que o governo do Estado não tem recursos financeiros e humanos para mantê-lo de acordo com os seus parâmetros originais.

\subsection{O Processo de Amadurecimento da Ca- deia de TBC}

O amadurecimento de posturas e re- 
flexões que se referem aos impactos da atividade no território da favela e aos anseios dos turistas e dos próprios moradores tornou-se perceptível em diversos relatos de entrevistados.

Os impactos gerados pelas atividades turísticas são reconhecidos e problematizados pelos agentes locais. O turismo na favela é observado pelos entrevistados numa perspectiva de longo prazo, na qual os impactos negativos são minimizados em favor da distribuição dos impactos positivos por toda a comunidade:

O turismo é uma atividade muito agressiva. É uma coisa que acaba com a estrutura da cidade e acaba com diversos pontos. Eu tenho uma preocupação muito grande com a possibilidade de minimizar o impacto. Impacto sempre vai ter, mas qual é a principal maneira de fazer e ajudar todo mundo? (Entrevistado 3)

Benatti \& Silva (2011: 433) entendem que "a aceitação da atividade em sua localidade pode trazer benefícios, seguida da vontade de participar e planejamento adequado, ocasionando em um relacionamento saudável entre morador e turista, de forma harmoniosa, paciente e respeitável à sua criação, costumes e modos de vida". Esses benefícios oriundos da aceitação do turismo na favela podem ser percebidos em afirmações de entrevistados que ilustram a diferença de visão em relação aos atores sociais que promovem o turismo na favela:

Hoje a comunidade vê nosso trabalho com outros olhos. Nós somos os moradores das favelas que fazemos o turismo acontecer aqui dentro. Acho que a percepção do morador em relação a nós é positiva, mas ainda é negativa com as pessoas que vêm de fora. O guia não tem uma orientação, então eles vão mesmo fazendo fotos das crianças, da mulher que tá na laje tomando um sol. Isso gera uma falta de educação e orientação. (Entrevistado 4)

É possível notar que a existência de práticas bem-sucedidas de empreendimentos turísticos e experiências profissionais também promove o bem-estar social e o senso de poder comunitário. Freire-Medeiros (2009) aponta que a prática do turismo em regiões com as características de uma favela incrementa o desenvolvimento econômico da região, a consciência social dos turistas e a autoestima das populações receptoras. Esse apontamento em relação à autoestima da comunidade é ilustrado em depoimento à pesquisa:

\begin{abstract}
O turista pode ter o diferencial de ter mais dinheiro, mas eu duvido que ele seja mais feliz. Aqui existe senso de comunidade. As pessoas se ajudam, conversam, se apoiam. Mesmo tendo seus problemas sociais que não são supridos pelas secretarias de governo - tanto municipal, quanto estadual ou federal. Eles fazem da dificuldade o seu desenvolvimento. Isso pra gente é o maior orgulho. (Entrevistado 1)
\end{abstract}

O desenvolvimento do local e da cidadania dos envolvidos no processo de TBC na favela depende fundamentalmente do encontro e da autenticidade. Por meio de estratégias que tornem cada vez mais natural a interação que ocorre entre turista e morador, a favela se tornará cada vez mais habitual ao cotidiano urbano, o que diminui o estranhamento e pensamentos preconceituosos baseados em estereótipos. A cadeia de TBC da favela tem conhecimento da atratividade e 
peculiaridade de seus serviços e das oportunidades atreladas à oferta de tais serviços: a inclusão social, a quebra de estereótipos e a autonomia econômica.

O turista do Rio de Janeiro vem com essa vontade de experimentar o que é real e a gente vê que algumas agências de fora deixam tudo muito fake [falso]. O Rio de Janeiro não é só o Cristo Redentor. É Lapa, hip-hop, baile de rua e baile funk. É experiência de artista de rua. É o moleque que vende bala no camelô que é engraçado. Isso é Rio de Janeiro. $O$ turismo em favela, o TBC e o tour de experiência vieram pra agregar valor trazendo a perspectiva diferente: inserir os favelados no segmento do turismo, abrir a possibilidade do turismo nas favelas em um segmento que é elitizado, e a gente conseguiu quebrar e furar esse bloqueio. Ter e gerir o próprio negócio. (Entrevistado 2)

É importante que a comunidade busque empreender a atividade turística em seu território de acordo com seus desejos e expectativas, buscando seu empoderamento político e evitando, assim, os efeitos negativos gerados pela prática do turismo. Haverá mais chance de se preservar o bem-estar econômico, social e cultural da comunidade local se for garantido o protagonismo de seus próprios residentes (Rodrigues, 2014).

\section{CONSIDERAÇÕES FINAIS}

Este trabalho foi desenvolvido com base na análise do processo de turistificação da favela Santa Marta e da constituição de uma cadeia de TBC no local. Considerando-se o objetivo de analisar e discutir os efeitos da existência de iniciativas de TBC em uma favela do Rio de Janeiro, é razoável dizer que a partir deste estudo é possível apontar perspectivas e experiências de visitantes e moradores que desencadeiam novas possibilidades sociais, econômicas e culturais no turismo em favela.

Partindo de um procedimento de free elicitation e de um estudo quantitativo sobre convergências e contrastes de opiniões entre moradores e turistas, foram obtidos resultados relevantes em relação à interação de visitantes e visitados durante essas experiências. No estudo qualitativo foram analisados e investigados com maior cuidado alguns assuntos que despertam interesse nessa área de estudos e permeiam discussões a respeito do turismo em favela e do TBC.

Seja pelo desejo de vivenciar diferentes experiências turísticas ou pela vontade de compartilhar fotos e relatos com seus amigos e familiares, os turistas reconhecem que durante as visitas ocorre a oportunidade de aproximação à diversidade cultural das favelas. Esses turistas, de forma geral, consideram esclarecedora a experiência e a oportunidade de percorrer e reconhecer as ruas de uma favela. Por muitos anos, o turismo em favelas foi muito criticado por representantes oficiais e pela maioria de classe média e alta brasileira, sendo considerado uma atividade desprezível, por "denegrir a imagem do país devido à exposição da população pobre" (Freire-Medeiros, 2009: 45). De acordo com o resultado deste estudo, o interesse turístico pode ocorrer não por causa da pobreza, mas por diversos outros fatores. Apesar do histórico contraste social e do poder de influência da mídia (Rodrigues, 2014), os visitantes geralmente percebem a favela de maneira diferente da impressão que tinham em 
seus países.

Os resultados desta pesquisa apontam que há possibilidades para o incentivo a alternativas de experiências turísticas que fomentem o desenvolvimento social em âmbito local e interpessoal com base nos conceitos do TBC. O estreitamento de relações entre o visitante, quando ele possui consciência de seus impactos sociais, e o morador local, quando ele assume o protagonismo dos arranjos produtivos do turismo, parece ser benéfico para ambas as partes (Botelho, Egrejas $\&$ Bartholo, 2014). No trecho final das entrevistas pode-se observar a consciência a respeito dos efeitos do turismo por parte dos moradores que possuem nível elevado de envolvimento com o turismo.

Entretanto, é importante ressaltar que a presença do poder público, com políticas e ações efetivas que trabalhem para a integração efetiva das favelas ao território da cidade do Rio de Janeiro, é fator fundamental para que experiências estruturadas com base nos preceitos do TBC sejam possíveis e exitosas. O recente processo de esvaziamento das ações do governo do estado nas favelas cariocas, principalmente no projeto das UPPs, indica como a presença do Estado ainda é primordial e insubstituível.

É importante ressaltar que perfis de turistas e dinâmicas de relacionamentos entre turistas e moradores encontram-se em permanente processo de mudanças. Apesar da existência de uma grande variedade de estudos de experiências de TBC, ainda é redu zida a quantidade de estudos sobre tais experiências em ambientes urbanos como as favelas, assim como são poucas as pesquisas cuja temática central é o protagonismo dos moradores em iniciativas locais de turismo. A sustentabilidade dessas atividades também é um fator relevante principalmente no que se refere à percepção de impacto e efeitos nesses locais.

\section{REFERÊNCIAS}

Benatti C. \& Silva K. T. (2010). Identidade cultural e gestão participativa na atividade turística. Encontro Nacional de Turismo de Base Local. ENCONTRO NACIONAL DE TURISMO DE BASE LOCAL. 13., 2014. Anais... Juiz de Fora, MG, 10 a 13 de novembro de 2014. - Juiz de Fora.

Botelho, A. C. B.; Egrejas, M. \& Bartholo, Roberto (2014). A turistificação da zona portuária do Rio de Janeiro, Brasil: por um turismo situado no Morro da Conceição. Revista Brasileira de Pesquisa em Turismo, 8(2), pp. 286-300.

Bursztyn, I. \& Bartholo JR. R. S. (2012). O processo de comercialização do turismo de base comunitária no Brasil: desafios, potencialidades e perspectivas. Sustentabilidade em Debate, 3, p. 97-116.

Carvalho, F. C. \& Silva, F. D. (2012). Turismo e favela: um estudo sobre a Favela Santa Marta e o papel das Unidades de Polícia Pacificadora no Rio de Janeiro. Cadernos do PROARQ - Programa de Pós-Graduação em Arquitetura, 19.

Catão, H. (2014) Turismo comunitário, tradicionalidade e reserva de desenvolvimento sustentável na defesa do território nativo: aventureiro - Ilha Grande/RJ. Revista Brasileira de Pesquisa em Turismo, 8(2), pp. 361-379.

Cejas, M. I. (2006). Tourism in shantytowns and slums: a new "contact zone" in the era of globalization. Intercultural Communication Studies XV, 2006. Disponível em:

$<$ http://www.uri.edu/iaics/content/2006v15n2/20\%20M\%A8\%AEnica\%20In\%A8\%A6s\%20Cejas.pdf>. Acesso em: 20/01/2016.

Cisne, R.; Gastal, S. (2011). Nueva visión sobre los itinerarios turísticos: Una contribución a partir de la complejidad. Estudios y Perspectivas em Turismo. 26, pp. 1449-1463. 
Corrar, L. J., Paulo, E. \& Filho, J. M. D. (Coord.) (2012). Análise multivariada para cursos de Administração, Ciências Contábeis e Economia. São Paulo: Atlas.

Creswell, John W. Projeto de pesquisa: métodos qualitativo, quantitativo e misto. 2a Edição. Porto Alegre: Artmed, 2007.

Fabrino, N. H. (2013). Turismo de base comunitária: dos conceitos às práticas e das práticas aos conceitos. Dissertação (Mestrado) - Centro de Desenvolvimento Sustentável. Universidade de Brasília, Brasília.

Fratucci, A. C. (2008). Refletindo a dimensão espacial do turismo a partir das lógicas de apropriação dos espaços dos seus agentes sociais In: V Seminário Anptur, 5., 2008. Anais... Belo Horizonte.

Figueiredo, A. A.; Mayer, V. F.(2010). A imagem dos destinos turísticos: a cidade de São Paulo sob o olhar de jovens do Rio de Janeiro. Turismo em Análise. 21(3).

Freire-Medeiros, B. (2009). Gringo na laje: produção, circulação e consumo da favela turística. Rio de Janeiro: FGV.

Freire-Medeiros, B., Coelho, A. \& Monteiro, L. (2012). Turismo em favelas: um desafio de sustentabilidade. Cadernos FGV Projetos, 7, pp. 108-113.

Freire-Medeiros, B., Vilarouca, M. G., Menezes, P. (2013) International tourists in a pacified favela: profiles and atitudes: the case of Santa Marta Rio de Janeiro. Die Erde (Berlin), 144, pp. 147-159.

Gaffney, C. T. (2013). Forjando os anéis: A paisagem imobiliária pré-olímpica no Rio de Janeiro. e-metropolis: Revista eletrônica de Estudos Urbanos e Regionais, 15, p. 8-24.

Garcia, F. A., Macia R. C. \& Vazques, A. B. (2015). Resident's attitudes towards the impacts of tourism. Tourism Management Perspectives, 13, pp. 33-40.

Gómez, C. R. P., Falcão, M. C., Castillo, L. A. G., Correia, S. N., Oliveira, V. M. (2015). Turismo de Base Comunitária como inovação social: congruência entre os constructos. Revista de Turismo y Patrimonio Cultural, 13(5), pp. 1213-1227.

Hair J.F.J., Anderson, R. E., Tathan, R. L \& Black, W. C. (1998) Multivariate data analysis. 5a ed. Prentice Hall, New Jersey.
Irving, M. A. (2009) Reinventando a reflexão sobre turismo de base comunitária - inovar é possível? In: Turismo de base comunitária: Diversidade de olhares e experiências brasileiras. Rio de Janeiro: Letra e Imagem, pp. 108-119.

Klepsch, L. (2010). A critical analysis of slum tours: Comparing the existing offer in South Africa, Brazil, India and Kenya. Master in Sciences and Tourism Management - Université Libre de Bruxelles - Institut de Gestion de L'Environnement et d"Amenagement du Territoire - Faculte des Sciences.

Knafoo, R. (1996). Turismo e território: por uma abordagem científica do turismo. IN: Rodrigues, A. A.B. Turismo e geografia: reflexões teóricas e enfoques regionais. São Paulo: Ed. Hucitec, 1996. p. 62-74.

LTDS (2011). Relatório técnico: marco referencial teórico para o turismo de base comunitária. laboratório de tecnologia e desenvolvimento Social. Rio de Janeiro: PEP/COPPE/UFRJ.

Ma, B. (2010). A Trip into the controversy: a study of slum tourism travel motivations. Penn Humanities Forum on Connections.

Machado, D.S.M. (2007). Turismo de Favela e desenvolvimento sustentável: um estudo do Turismo de Favela no bairro de Vila Canoa, Zona Sul do Rio de Janeiro. Dissertação (Mestrado em Serviço Social) - Departamento de Serviço Social da PUC-Rio.

Mekawy, M. A. (2012) Responsible Slum Tourism: Egyptian Experience. Annals of Tourism Research, 39 (4), pp. 2092-2113.

Menezes, P. V.(2014) Os rumores da pacificação: a chegada da UPP e as mudanças nos problemas públicos no Santa Marta e na Cidade de Deus. UFRJ - IFCS. Dilemas: Revista de Estudos de Conflito e Controle Social.

Nunkoo, R., Gursoy, D. (2012). Residents' support for tourism: an identity perspective. Annals of Tourism Research, 39(1), 243-268.

O'leary, S., Deegan, J. (2005) Ireland's image as a tourism destination in: France: attribute importance and performance. Journal of Travel Research, 43, pp. 247256, fev. 
Rodrigues, M. (2014) Tudo junto e misturado: O Almanaque da Favela: Turismo na Favela Santa Marta. Rio de Janeiro: Mar de Ideias. 1. Ed.

Sampaio, C. A. C. \& Coriolano, L. N. (2009). Dialogando com experiências vivenciadas em Marraquech e América Latina para compreensão do turismo comunitário e solidário. Revista Brasileira de Pesquisa em Turismo. 3(1), pp. 4-24.

Sansolo, D. \& Bursztyn, I. (2009). Turismo de base comunitária: potencialidade no espaço rural brasileiro. Turismo de base comunitária: Diversidade de olhares e experiências brasileiras. Rio de Janeiro: Letra e Imagem, pp. 142-161.

Sharpley, R. (2014). Host perceptions of tourism: A review of the research. Tourism Management, 42, pp. 37-49.

Silva. D. R., Corban, S., Sampaio. C.A.C. \& Grimm I.J. (2015) Turismo comunitário en favela: um estudio del Favela Inn Hostel, Chapéu Mangueira, Rio de Janeiro, Brasil. Estudios y Perspectivas en Turismo, 24.

Silva, F P. S.; Martins, L. C. A. (2012) Mergulhando em memórias, tecendo culturas e construindo histórias: o diálogo entre a história e o turismo de base comunitária. Sustentabilidade em Debate - Brasília, 3 (2), pp.6170.

Smith, V. L. (1999) Host and guests: the anthropology of tourism. Philadelphia, USA: University of Pennsylvania Press. 2nd ed.

Spampinato, E. (2009) Turismo em favelas cariocas e desenvolvimento situado: a possibilidade do encontro em seis iniciativas comunitárias. Dissertação (Mestrado) - UFRJ/COPPE, Rio de Janeiro.

Woosnam, K. (2012) Using emotional solidarity to explain residents' attitudes about tourism and tourism development. Journal of Travel Research, 51(3), pp. $315-327$.

\section{Dados dos autores}

\section{Apoena Dias Mano}

Bacharel em Tuismo pela Universidade Federal Fluminense. Especialização em Sociologia Urbana na Universidade Estadual do Rio de Janeiro. Membro pesquisador do LABCONS - Laboratório de Estudos de Consumo e Comportamento. Temas de interesse: desenvolvimento sustentável; turismo em favela; Turismo de Base Comunitária; comportamento do consumidor. E-mail: apoenamano@id.uff.br

\section{Veronica Feder Mayer}

Professora associada da Universidade Federal Fluminense. Doutora em Administração. Coordenadora do Curso de Bacharelado Turismo da Faculdade de Turismo e Hotelaria, membro do corpo docente do Mestrado Acadêmico em Turismo (PPGTUR/UFF), coordenadora do LABCONS - Laboratório de Estudos de Consumo e Comportamento. Suas linhas de pesquisa são consumo e novas demandas no turismo; planejamento, marketing e relacionamento com stakeholders; psicologia dos preços. E-mail: veronicamayer@id.uff.br

\section{Aguinaldo Cesar Fratucci}

Professor associado da Faculdade de Turismo e Hotelaria da Universidade Federal Fluminense. Doutor e mestre em Geografia. Coordenador do Programa de Pós-Graduação Stricto Sensu em Turismo da Universidade Federal Fluminense, líder do Grupo de Pesquisa CNPq "Turismo, gestão e territórios". Áreas de interesse: gestão pública de turismo; processos de turistificação de espaços; planejamento e gestão de destinos turísticos; epistemologia do turismo. E-mail: acfratucci@turismo.uff.br 